\title{
NARRATING THE SELF AND THE OTHER(S): \\ BRAZILIAN UNDERGRADUATE STUDENTS' \\ RESPONSIVENESS TO ENGLISH, ELT AND LITERACY \\ PRACTICES IN LEARNING AUTOBIOGRAPHIES
}

\author{
NARRANDO A SI E AO(S) OUTRO(S): A RESPONVIDADE \\ DE ESTUDANTES DE GRADUAÇÃO BRASILEIROS/AS AO \\ INGLÊS, ENSINO DE INGLÊS E PRÁTICAS DE LETRAMENTO \\ EM AUTOBIOGRAFIAS DE APRENDIZAGEM
}

Paula Tatianne Carréra Szundy*

\begin{abstract}
This article draws on constructs of the discursive dialogic analysis designed by the Circle of Bakhtin, on the notion of language ideologies and on a transgressive view of Applied Linguistics to interpret how undergraduate students majoring in English and Portuguese from a public university in Rio de Janeiro, Brazil, position themselves in relation to English, English Language Teaching and literacies in written learning autobiographical narratives. The learning autobiographies were produced by students in the beginning of their college education as future English and Portuguese teachers in an academic writing course. Parting from the assumption that what we come to identify as our thoughts, beliefs and "truths" is constructed in the interpersonal level before becoming "ours" (Voloshinov 1929 [1986]) and aligning myself with an ideological view of literacies (Street 1984, 1995 [2014], 2009), I analyze the ideologies about languages and literacies taking into consideration both the micro-context in which the autobiographies were produced and the macro societal levels that influenced how the selves and the others are positioned in the narratives.
\end{abstract}

Keywords: learning autobiographies; language ideologies; literacies

\section{RESUMO}

O presente artigo recorre a construtos da análise dialógica do discurso desenhada pelo Círculo de Bakhtin, à concepção de ideologia linguística e a uma perspectiva transgressiva de Linguística Aplicada para interpretar como alunos/as de graduação de Letras Português/ Inglês de uma universidade pública do Rio de Janeiro, Brasil, posicionam-se em relação ao Inglês, Ensino de Inglês e letramentos em escritas narrativas autobiográficas sobre os próprios processos de aprendizagem. As autobiografias de aprendizagem foram produzidas pelos/as estudantes que estavam iniciando sua formação como futuros/as professores/as de língua inglesa e portuguesa em um curso de escrita acadêmica. Com base no pressuposto de

\footnotetext{
* Universidade Federal do Rio de Janeiro, UFRJ, Rio de Janeiro, RJ, Brasil. ptszundy@letras.ufrj.br Orcid: https://orcid.org/0000-0001-8465-1406
} 
que aquilo que identificamos como nossos pensamentos, crenças e "verdades" é construído no nível interpessoal antes de se tornar propriamente "nosso" (Voloshinov 1929 [1986]) e alinhando-me à uma perspectiva ideológica dos letramentos (Street 1984, 1995 [2014], 2009), busco compreender as ideologias sobre línguas e letramentos a partir de interrelações entre o micro contexto em que as autobiografias foram produzidas e os níveis macro sociais que influenciaram posicionamentos sobre si e sobre outrem nas narrativas.

Palavras-chave: autobiografias de aprendizagem; ideologias linguísticas; letramentos

\section{INTRODUCTION ${ }^{1}$}

As privileged sites where participants (de/re)construct identities and sociabilities, narratives have been thriving epistemological and methodological objects in Applied Linguistics. This growing interest (see, for example, PAVLENKO, 2001a, 2001b, 2007; VITANOVA, 2004; COFFEY; STREET, 2008; COFFEY, 2010; BAMBERG, 2010; ROMERO ET AL, 2010; GEORGAKOPOULOU, 2013; SANDHU 2014; BASTOS; BIAR, 2015) is usually inscribed in an epistemological movement known as the discursive and narrative turn in humanities and social sciences. Drawing on the understanding that the stories we tell are invaluable means to make sense of our experiences and positions in the world, Bastos and Biar (2015, p. 98) argue that "the study of narratives that emerge in spontaneous, institutional or research contexts" can boost our comprehension about the social life and the role played by discourses in its construction and transformation. Applied linguists' interests in narratives are as vast as the innumerous stories that can be told through them and have included issues related to gender, sexuality, violence, immigration, work, language learning/teaching, language ideologies, among many others.

Pavlenko (2007) advocates that studies on L2 learners' narratives in Applied Linguistics have positioned them as embodied and agentive rather than abstract and unidimensional subjects. Concerning how students' learning narratives are approached in Applied Linguistics, the author criticizes thematic analyses that presuppose that themes, patterns and categories merely emerge from narratives without any influence from the researcher's background. Alternatively, Pavlenko (2007:175) proposes that researchers should reflect upon and position themselves about the conceptual lens from which they choose to look at narratives so as "to make their assumptions clear, conceptual constructs explicit, and analyses replicable". Additionally, she defends the point that the interplay between content,

1. Agradeço à CAPES e ao CNPq pelo suporte financeiro para realização desse estudo, através de bolsas de estágio sênior (processo $\mathrm{n}^{\circ}$ BEX 2817/15-2) e produtividade em pesquisa (processo $\mathrm{n}^{\mathrm{O}}$ 307218/2018-0), respectivamente. 
context and form be considered in the analysis, which should inter-relate micro contextual aspects with cultural, socioeconomic and ideological macro issues that contribute to (re) shape the meanings performed by learners in their narratives.

Sharing the assumption of the interplay between micro contextual aspects and macro societal issues in narratives, I focus on the ideologies about English, English language teaching and literacies entextualized by four undergraduate students in written learning autobiographies produced during an academic writing course I taught in a public university in Rio de Janeiro, Brazil, in the first semester of 2015. I draw on the notion of entextualization (SILVERSTEIN; URBAN, 1996) to interpret how the students position themselves and others as they narrate their learning trajectories into English in order to account for the fact that "truths" about what counts as valid learning/teaching experiences are recontextualized and resignified in the autobiographies from somewhere else. These "truths" are thus addressed as ideological, cultural and historical evaluative responses (VOLOSHINOV, 1929 [1986]) inscribed in the event-ness of life (BAKHTIN, 1920-24 [1999]).

The notion of entextualization as successive processes of decontextualization and recontextualization of discourses as they move across different contexts (SILVERSTEIN; URBAN, 1996) accounts, therefore, for both the situated and contingent character of the ideologies that frame responsive attitudes towards learning/teaching experiences in the students' autobiographies. This notion also accounts for the participants' agency in reframing these attitudes as they bring crystallized ideological systems into their narratives to (r) evaluate their experiences. In order to make sense of this ( $\mathrm{r}$ )evaluation process, I draw on the dialogic view of language designed by the Circle of Bakhtin (VOLOSHINOV ,1929 [1986]; BAKHTIN ; 1953 [2013]); on the notion of language ideologies (WOOLARD, 1998; KROSKRITY, 2004); and on an ideological model of literacies (STREET, 1984, 1995 [2014], 2009 in order to interpret what students entextualize as (non) legitimate ideologies concerning languages, learning/teaching and literacies in their narratives.

The discussion in this paper is organized in three sections. The first one outlines the theoretical framework that informs the interpretive paths privileged in the analysis of students' learning autobiographies; the second contextualizes the autobiographies in relation to the literacy practices in which they are inscribed, the third presents the analysis of the narratives. Finally, I conclude with a reflection about the potentials of learning autobiographies to foster (meta)reflexivity in teacher development practices. 


\section{LEARNING AUTOBIOGRAPHIES AS DIALOGIC-IDEOLOGICAL LITERACY PRACTICES}

The choice of written learning autobiographies as a genre to foster future teachers' reflection about their learning trajectory is based on my ideological assumption that a theoretically framed reflection about our learning and professional journeys can figure as a meaningful semiotic instrument in teacher education. Its meaningfulness lies in the fact that in the process of (re)narrating their learning stories and positioning themselves about their experiences, learners (de/re)contextualize settings, people and actions that they judge relevant in their learning process in order to resignify them. In this sense, "autobiographies (formal or informal) should be viewed as a set of procedures for 'life making'" (BRUNER, 2004, p. 692).

As "life making" procedures, narratives, according to Bruner (2004), cannot be approached as a reflection of life itself. Emphasizing the constructionist nature of narratives, Bruner addresses them as interpretive accomplishments characterized by a high degree of reflexivity and instability. It is this reflective and instable nature of life stories that make them "highly susceptible to cultural, interpersonal, and linguistic influences" (BRUNER, 2004, p. 694). Bruner's belief that the forms through which autobiographical beings in narratives are engendered by the possible lives that can (or cannot) be told in one's culture inscribes autobiographies in what Voloshinov (1929 [1986]) understands as the material embodiment of the ideological sign. In this perspective, life stories cannot be viewed as reflections or expressions of our inner thoughts. Since consciousness is interindividually constructed in social intercourses (VOLOSHINOV, 1929 [1986]), what we come to understand as our autobiographies is in fact dialogically (re)defined and thus shaped by the social identities we perform in our lifeworlds.

Thus, a dialogic rather than a representational account can better capture "how narratives position the narrator in an ongoing dialogue with other speakers" (WORTHAM 2001, p. 1). For Wortham (2001), the interactional power of narratives is related to the fact that rather than merely representing certain states of mind and/ or experiences, they accomplish social actions, having, therefore, a performative nature. Inspired by a performative approach to narratives largely influenced by feminist studies, Wortham emphasizes the ongoing, fragmented, open-ended and heterogenous character of the self in narratives, who positions him/herself in relation to the multifaceted voices that inhabit his/her autobiographical memoirs within established cultural patterns. Nevertheless, depending on the literacy practices in which learning autobiographies are embedded, they can contribute to destabilize established cultural patterns and become arenas for competing ideologies. A 
deeper comprehension about how certain views of languages and literacies are (de) legitimized and (de)stabilized in students' learning autobiographies can be achieved through a dialogic-ideological approach to this literacy practice.

The dialogic-ideological approach privileged in the analysis of learner's autobiographies rests on the inter-related stances I assume regarding ideologies, language and literacies in teacher education practices. Anchored in a transgressive view of Applied Linguistics (MOITA LOPES et al 2006; SZUNDY; FABRÍCIO, 2019 ), I assume that in future English teachers' pre-service education, developing a positioning about what we call English goes necessarily through the de/ reconstruction of crystallized linguistic ideologies that view languages as stabilized and universal systems of norms, which are reiterated in different social contexts and dictated by idealized native speakers.

Opposing these views, researchers such as Blommaert (2005, 2010), Dewey and Leung (2010); Leung (2013), Moita Lopes et al (2013), Szundy and Fabrício (2019) propose that we think about languages as linguistic resources that we mobilize and (re)construct in situ. These resources are constantly subject to variations imposed by non-linguistic aspects such as agency and the responsive attitude of face-to-face/virtual/projected interlocutors, who are always historically, culturally and institutionally situated. In such a conception, what we call English, Spanish, French, Portuguese and so forth depends on the semiotic resources we are able to employ to negotiate meanings in specific communicative situations. It depends, equally, on how participants evaluate mobilized (non)linguistic resources in the course of interaction and on their "beliefs, or feelings, about languages as used in their social worlds" (KROSKRITY, 2004, p. 498).

The implicit or explicit responsive attitudes towards language assumed by people in the social world are defined by Kroskrity (2004) and Woolard (1998) as language ideologies. The idea that both the (inter)actions performed within unsystematic daily informal social practices and those realized within systematic formal institutionalized literacy practices shape our positions about language makes the conception of language ideology account for both the behavioral and crystallized ideologies envisioned by Voloshinov (1929 [1986])². Voloshinov (1929

2. According to Voloshinov (1929[1986]), each social sphere reflects and refracts reality distinctly. The aggregate of life experiences and the way they are verbally and non-verbally expressed constitute the behavioral ideologies, while the set of utterances originated from more complex and structured activities from the political, media, educational, academic, religious spheres, among others, are classified as historically crystallized ideologies, which are understood as crystallized forms originated from behavioral ideologies. In situated language practices uses, behavioral and crystallized ideologies are imbricated in complex, and frequently, conflicting ways. 
[1986]) views the interrelations between behavioral and crystallized ideologies as a dialectical one since both are subject to mutual transformations. He also emphasizes that behavioral ideologies evolve into crystallized ones once they are systematized in the course of human activities. This dialectical and interconstitutive nature between laypeople's and institutionalized ideologies is also portrayed in the notion of language ideology, which, according to Silverstein (1998), can only be understood within a discourse of interpretation of dialectical indexical processes. Thus, the fact "that people have ideologies of language [...] is a necessary entailment of the fact that language, like any social semiotic, is indexical in its most essential modality" (SILVERSTEIN, 1998, p. 130).

Starting then from the assumption that what counts as good/bad, acceptable/ unacceptable literacies in English is indexically inscribed in situated ideological formations, the exposition of future English teachers to reading and/or writing practices in which traditional views of English are challenged may contribute to reshape their narratives in learning autobiographies. Additionally, the engagement in academic literacy practices that problematize native speakers' exclusive prerogative towards what counts as English can contribute to destabilizing future teachers' of English as an Additional Language ${ }^{3}$ views on language and legitimize as well as widen the resources with which they operate when using English in their own academic writing. Ultimately, it aims at fostering a "political literacy", comprehended as a way to transform future teacher's conceptions about language so as to trigger the additional view to "see beyond, beyond their boundaries without despising them; beyond their values without losing them; beyond their country without abandoning its cultures" (CELANI, 2004, p. 121).

The norms of English uses based on an ideal native speaker are criticized by scholars affiliated to views of English as a lingua franca or world/multinational/ border/additional language (HOUSE, 2003; JENKINS, 2007; LEFFA, 2002; RAJAGOPALAN, 2004; MOITA LOPES 2008, DEWEY AND LEUNG, 2010; SEIDLHOFER, 2011; SZUNDY, 2017, among others). And similarly, autonomous

3. Despite my awareness of the fact that the lexical choice to refer to the status of English as lingua franca, world, international and/or additional language inscribe authors in distinct crystallized ideologies about language, I understand that all these terms share researchers' responsive attitude concerning native speakers' lack of prerogative towards the many uses of what we call English and towards the legitimacy of these uses for all those who use English as a communicative resource. My option for the qualifier additional to refer to English teachers in their pre-service education is justified by my belief that other languages constitute additional linguistic resources to students' linguistic repertoire. In this sense, the non-familiarity of this research participants with the academic register makes the uses of English (or even Portuguese) in academic literacy practices additional semiotic resources in a basic level of construction in their linguistic repertoires. 
models of literacies privileged until the 90's have, as stated by Leung and Street (2012a, 2012b), been the target of criticism by researchers who inscribe their works in the field of new literacy studies and, I would add, by those who advocate a pedagogy of multiliteracies. In both research contexts - that of ELF and of literacy studies - the criticism of more traditional approaches lies in their lack of responsiveness ${ }^{4}$ to situated language uses in contemporaneity. In this sense, the New London Group's criticism that the literacy pedagogy "has been a carefully restricted project - restricted to formalised, monolingual, monocultural, and rulegoverned forms (COPE; KALANTZIS et al, 2000, p. 9)" can be extended to the fields of English as Foreign/Second Language teaching/learning and teacher education.

The choice of the adverb carefully by the New London Group to qualify the restrictive character of literacy pedagogy indicates the authors' assumption that every literacy conception is ideologically situated. Consequently, the choice of one or more literacy models to orient teaching/learning and teacher education processes brings serious implications to all those involved in them. The adhesion to autonomous models of literacies, which distinguish social groups in literate and illiterate through the mastery of genres (usually written ones) legitimized by a school thought for a white, urban, heterosexual and supposedly homogeneous middle class can, in this sense, contribute to perpetuate inequalities and reiterate discriminatory social practices in relation to class, race, gender, religion etc.

It is my assumption that the affiliation to specific conceptions of literacies leads to educational and teacher education practices that are more or less prone to

4. The concept of responsiveness is central to the reflections drawn in this paper. It is based on the notion of responsive attitude and understanding proposed by the Circle of Bakhtin. Bakhtin (1953 [2013], p. 69) emphasizes that "all real and integral understanding is actively responsive, and constitutes nothing other than the initial preparatory stage of a response (in whatever form it may be actualized). And the speaker himself is oriented precisely toward such an actively responsive understanding. He does not expect passive understanding that, so to speak, only duplicates his own idea in someone's else mind. Rather, he expects response, agreement, sympathy, objection, execution, and so forth (various speech genres presuppose various integral orientations and speech plans on the part of the speaker or writers). [...] Moreover, any speaker is himself a respondent to a greater or lesser degree. He is not, after all, the first speaker, the one who disturbs the eternal silence of the universe. And he presupposes not only the existence of the language system he is using, but also the existence of preceding utterances - his own and other's - with which his given utterance enter in one kind of relation or another (builds on them, polemizes with them, or simply presumes that they are already known to the listener). Any utterance is a link in a very complexly organized chain of other utterances". In this sense, when students reconstruct learning experiences in their autobiographical narratives, they engage in active answers with previous utterances which have been shaping their active understanding concerning what counts as English, English Language Teaching, literacies and so forth. 
respond to language uses in the contemporary world and to orient ethical choices in meaning construction processes (SZUNDY, 2014; OLIVEIRA; SZUNDY, 2014). This, then, justifies my option to reflect about the literacy practices in which future English teachers engage in their initial education from an ideological perspective of literacy (STREET, 1984). Street (1984, 1995 [2014], 2009) emphatically criticizes the autonomous model for anchoring in a pretended neutrality and universality which disguises its ideological orientations. He proposes an alternative and ideological model of literacy that "offers a more culturally sensitive view of literacy practices as they vary from one context to another "(STREET, 2009, p. 337).

For Street (1995 [2014) the pretense of neutrality in autonomous models of literacy leads to a universalizing, essentialist and ethnocentric focus on skills and functions in which the reasons why some forms of literacies are hierarchized over others are completely ignored. The functional explanations privileged by autonomous models tend to take literacies for granted without questioning how and why they were produced or whose interests they serve. They also tend to establish a great divide between oral and written genres as if the differences between speaking and writing weren't socially and culturally produced. In the ideological model proposed by Street, literacy practices are always embedded in power relations, making it fundamental to comprehend how participants (re/de)construct meanings during and about literacy practices in which they engage from a sociocultural perspective. From this premise, Street (2009, p. 337) suggests that every literacy program researched in the light of the ideological model should address the following questions: "What is the power relationship between participants? What are the resources? Where are people going if they take on one literacy rather than another literacy?".

In such a model, rather than focusing only on technical linguistic aspects that, in an autonomous perspective, can be replicated to other settings, it is fundamental to raise awareness about how the semiotic forms we use are socially and ideologically constructed (STREET, 1995 [2014]). In the ideologically situated approach to literacies presented by Street, it is also fundamental to scrutinize how literacy practices associated to schooling came to be more valued than other forms. Street (1995 [2014]) argues that autonomous models of literacies are replicated at schools through the distance that is established between the subject and language, the metalinguistic focus and the greater status attributed to reading and writing than to oral practices. Procedures of hierarchy, authority and control are, as Street reminds us, not only established through pedagogic practices in relation to texts, 
but also through the physical and institutional space, which is clearly separated from the spaces of our daily lives.

Despite this separation, Street (1995 [2004]) recognizes that the legitimacy of pedagogical literacies is constantly restated in other social spheres such as the family, the industry of educational software and games, the media, among others. In this sense, Street shares Bourdieu's (1986 [1991]) view that the gatekeeping processes of what counts as legitimate culture and as standard language exercised by the educational market are complexly commodified by several social agents, who constantly reinforce their values as symbolic capitals. In the learning stories narrated by students in their autobiographies, English is usually portrayed as a high valued commodity mainly for providing access to cultural repertoires that make its speakers experience (and feel part of) American and British mass culture. Therefore, the narrated learning experiences are constructed within literacy practices that transcend the walls of school and academia.

The next two sections focus on the contextualization of the students' autobiographies in relation to the wider literacy practices in which they are inscribed and on the data analysis.

\section{2. (RE)WRITING LEARNING TRAJECTORIES AS A LITERACY EVENT EMBEDDED IN LITERACY PRACTICES}

The distinction Street (1995 [2014], 2000) establishes between literacy events and literacy practices is an important one to inter-relate the micro situation of (re)writing learning autobiographies to the macro practices in which it is embedded. Expanding Heath's (1983) notion of literacy events as any situation in which written language plays a fundamental role in interaction, Street proposes the concept of literacy practices to encompass the wider historic-cultural settings that influence (and are also influenced by) the content, form and style of genres. He argues that:

[...] the concept of literacy practices is pitched at a higher level of abstraction and refers to both behavior and the social and cultural conceptualizations that give meaning to the uses of reading and/or writing. Literacy practices incorporate not only 'literacy events', as empirical occasions to which literacy is integral, but also folk models of those events and the ideological preconceptions that underpin them. (STREET, 1995, p. 2)

Given its wider scope, the concept of literacy practices can promote an ethnography of literacies in which the impact of written material in a community is situated into its intellectual traditions and ideologically (r)evaluated through 
a transcultural perspective (STREET, 1995 [2014]). Street thus proposes an approach that transcends the detailed description of literacy events to focus on the ideological stances assumed by participants in relation to them. Since such an approach shouldn't rely solely on the linguistic characteristics of a particular communicative event, Street's choice of ethnographic methods to approach literacy practices is in dialogue with Blommaert and Rampton's (2011) view that bringing the ethnographic apparatuses to (applied) linguistics and discourse analysis can provide interpretive directions towards a deeper reflexivity concerning the circulation and distribution of knowledge and power.

Relying on studies in the field of what Gee (1990) terms New Literacy Studies, and Street (2009) Literacy as Social Practice - LSP, Street argues that the following principles be taken into consideration in ethnographic studies based on an ideological model of literacies:

- literacies are practices embodied by identities and comprehensions about the meanings of being human;

- it is fundamental to relate meanings and daily uses of literacies in specific cultural contexts with the pedagogy of literacies;

- the complex interweavings between the local and the global need to be addressed in literacy studies;

- the transition from the description of specific literacy events to the conceptualization of literacy practices represents a central theoretical and empirical issue.

Having these principles in mind, the following subsection provides a description of the settings in which the literacy events focused in this paper is located. I then move on to the analysis of the ideological preconceptions that underpin the literacy practices that organize participants' (inter)actions.

\subsection{The macro and micro ideological settings}

Since I began teaching undergraduate courses to future English teachers at the Language Faculty of the Federal University of Rio de Janeiro (UFRJ) in September 2009, the uncritical identification of many freshman students with an idealized British and/or North American variety of English called my attention (SZUNDY, 2013). Having a metalinguistic orientation, the bachelor's degree in English requires a considerable degree of proficiency from freshman students to attend specific courses related to grammar, written and oral discourses, which are 
taught in English from the beginning of their undergraduate studies. Despite the fact that this linguistic competence allows the access to complex academic literacy practices in English, students' self-perception as competent speakers didn't seem to provide them with the necessary critical view to see beyond idealized native North American and British models, which they assumed as the ones to be linguistically and culturally imitated.

It became then necessary to make academic writing in English a space to deconstruct crystallized language ideologies through the reading of papers and book chapters that could destabilize these ideologies. Amongst other things, this involved reflective (re)writing in genres such as note-taking, learning autobiography, summary, academic review, reflective diary, virtual forums etc. From this perception, I decided to include the topic of English as Lingua Franca/World English as a central one in the course Academic Writing I, which can be attended by students from the second period of their undergraduate studies in Portuguese and English on.

The literacy practices in which future English teachers engage are somehow influenced by their responsive understanding of the objectives listed in Table 1, extracted from the Course Plan related to the $1^{\text {st }}$ semester of 2015, when the excerpts of learning autobiographies analyzed in the next section were produced.

\section{Table 1. Objectives of the course Academic Writing I}

\begin{tabular}{|c|c|}
\hline \multicolumn{2}{|r|}{ ObJeCtives } \\
\hline$\checkmark$ & $\begin{array}{l}\text { Develop students' linguistic-discursive capacities to produce three important genres that } \\
\text { organize activity in the academic sphere: professional autobiography, summary, academic } \\
\text { review. }\end{array}$ \\
\hline$\checkmark$ & $\begin{array}{l}\text { Interrelate the written production of academic genres with a variety of reading activities in } \\
\text { order to trigger the analysis of content, organizational structure and style of the genres so as } \\
\text { to provide a critical stance towards knowledge production in the academic sphere. }\end{array}$ \\
\hline$\checkmark$ & $\begin{array}{l}\text { Articulate written comprehension and production with awareness raising and critical positioning } \\
\text { on issues related to English as an Additional Language (EAL) teaching and learning processes, } \\
\text { writing responsibility and English as a Lingua Franca so that writing becomes a meaningful } \\
\text { instrument to (re)construct one's view about linguistic and educational issues involved in } \\
\text { English Language Teaching (ELT). }\end{array}$ \\
\hline$\checkmark$ & $\begin{array}{l}\text { Foster students' reflection on their own learning process through the reflective writing of } \\
\text { learning narratives and the participation in online discussion groups. }\end{array}$ \\
\hline & $\begin{array}{l}\text { Engage students in meaning construction through the use of new tools and genres from the } \\
\text { digital sphere so as to provide opportunities to operate critically with multiliteracies. }\end{array}$ \\
\hline
\end{tabular}

A look at the lexical choice privileged in these five objectives can provide meaningful insights into the ideological landscapes in which the professor's views concerning language, literacies and teacher education are settled. Her uneasiness in relation to students' own language ideologies is indexed in the election of English 
as a Lingua Franca as one of the course topics and in the purpose connected to this choice of making writing a meaningful instrument to (re)construct one's view about linguistic and educational issues involved in English Language Teaching (ELT). Although the focus on the linguistic-discursive aspects of the genre could lead to the reproduction of autonomous models of literacy in which generic structures are abstracted from their contexts to be reified in a number of different situations, the analysis of genre content, compositional structure and style so as to provide a critical stance towards knowledge production in the academic sphere portrays the possible shift to an ideological perspective of literacy. The affiliation to a constructionist and socio-historical language ideology can be noticed in the fifth objective, which indicates that genres are seen as meaning construction tools rather than stabilized linguistic entities. Finally, the fourth objective seems to give learning narratives the status of dialogic life-making genres (WORTHAM, 2001; BRUNER, 2004).

The fact that the students' learning autobiographies were (re)written during two distinct moments of the course - in the beginning and towards its end - also indicates that the life-making in autobiographies could be changeable as narrators further develop their competence to (de/re) construct more theoretically informed views about their learning experiences and memories. While in the first moment, the learning stories were shared in an online forum at Moodle, commented on by classmates and reviewed by the course monitor; in the second, they were rewritten in a document template and then uploaded at Moodle to be commented and graded by me. In addition to a detailed description on how this final version should expand the first one in terms of content and form, I proposed seven questions to orient the rewriting process: 
Table 2. Questions to orient the rewriting of learning stories

1. Taking into reconsideration your English learning experience at school, courses, college, how would
you characterize your teachers' and/or professors' views of language, especially the English language?
Do you think these views were framed on a critical conception of English as a Lingua Franca, on a
traditional conception of English as a Foreign Language, on a "blind" imitation of the native model?
Frame your evaluation with specific examples of activities, actions, attitudes etc.
2. Why was the learning process experienced in private courses idealized (or not) in your or your
colleagues' learning narratives? What kind of critique could you (re)construct about this ideal view
in the light of concepts such as linguistic and cultural imperialism, World English, English as a lingua
franca, native x non-native teachers, multiculturalism, global x local issues etc.?
3. How different has your learning experience been at UFRJ? How do you evaluate the education you
are getting at college taken into considerations the issues mentioned above (in question 2)?
4. How has your view about language and teaching been redesigned since you started college?
5. How has your engagement/lack of engagement in the students' strike contributed to frame your
view as a future language teacher/professional?
6. What other learning contexts and spheres besides school or course can reshape our knowledge
and views about language? How have they influenced your learning trajectory? How would you bring
them to your future teaching practice?
7. Why did you choose a specific image to illustrate your learning trajectory? Would you keep that
picture? Why or Why not? What other images, genres, videos could be brought into the reflection to
depict the changes you have been going through?
8. Any other aspects you consider relevant in your learning history.

Despite the influence of these questions on students' positions, especially taking into consideration the asymmetrical power relations and the use of their learning autobiographies' final version as a summative assessment, the ways students will choose (or not) to address the issues I proposed and their level of awareness towards them are heterogeneous. Such heterogeneity is certainly influenced by the fact that learning stories are reassessed in terms of different stances to lifeeventness (BAKHTIN, 1920-24 [1999]) and within conflicts between every day and crystallized ideological systems, as I will argue in the next section.

\section{RESPONSIVENESS TO ENGLISH, ELT AND LITERACY PRACTICES IN LEARNING AUTOBIOGRAPHIES}

This section aims at exploring how Alexandra, Luiza, Lucas and Tiago ${ }^{5}$ construct meanings about their learning trajectory into English in their narratives. Their responsive attitudes toward what count as legitimate teaching and learning trajectories and meaningful literacy practices in English are interpreted in the light

5. The four students expressed their written agreement about addressing them by their first real names in this paper. 
of the discursive dialogic analysis of language designed by the Circle of Bakhtin in dialogue with an ethnographic approach to literacy studies (STREET, 2009). I start the analysis addressing the generic structure of the autobiographies and the emotional-volitional responsiveness indexed in the titles the students chose to refract their learning trajectories. Following the stance they take about what English means to them in the metaphors that compose the titles of their autobiographies, I rely on longer narrative excerpts to interpret the students' ideologies concerning (non)legitimate literacies and teaching-learning experiences in English. The excerpts selected for the analysis depict my own responsiveness toward the most relevant (language) ideologies (de/re)constructed by students in their narratives. The selection portrays how students' stances to their learning experiences are embedded in more emotional and/or academic responses depending on the kind of literacy events they describe.

The stances assumed by each student in their autobiographies are at the same time united by the compositional structure of the genre (BAKHTIN, 1953 [1986]) and somehow separated by their distinct emotional-volitional responsiveness (VOLOSHINOV, 1929 [1986]) towards learning events. In terms of generic form, the four written learning autobiographies are characterized by the temporal sequence that Labov and Waletzky (1967) identify as the basic framework of narratives. The four students thus choose to begin telling their learning stories from childhood (It all started with my family's move abroad in 2003. At six years old, I was [...] [Luiza]; Ever since I was a little kid, I had a lot of contact with English. [Tiago]). They then progress into the practices, people and places that shaped their gradual immersion into the language (Joining an English course was a buge motivation for me to start listening to British music. [Alexandra]; Still very young, I continued my learning process in Wizard; The last English course that I went to was CNA. [Lucas]). And they finish by delving into the present (English holds a very important place in my heart [...] [Luiza]; The way I see it, our main job, as teachers is to open up the eyes of the students [...] [Tiago]) or expressing hopes for the future (For the future, I just hope that UFRJ keeps belping me to learn more and to turn myself in a good professional. [Lucas]; As for my next three years at UFRJ, I'm looking forward to the English Literature classes [...] [Alexandra]).

The distinctive volitional tones concerning the roles played by English in their lives can be initially grasped by referring to the titles each one chose for their learning autobiography: A Journey Into a Different World: My Learning Experience [Luiza]; My Wonders of English [Tiago]; English - Always by my side [Lucas]; My unfinished learning trajectory into English [Alexandra]. Through these titles, the students metaphorically place themselves in relation to their learning journeys and give the reader a glimpse 
of what English means to them. While the ideology of foreign languages as a means to be exposed to alterity and to dig into the wonders of unknown worlds seems to be expressed in Luiza's journey into a different world and in Tiago's wonders of English, the belief of learning as an ongoing process is the one portrayed in the titles chosen by Lucas and Alexandra.

When contrasted with the learning trajectories constructed in their narratives, these images do make sense. For Luiza, the journey into a different world began when she was six as she moved with her family to Peru and started attending a bilingual school where she had to learn two new languages — both English and Spanish —in a very "brutal" way: by being thrown into a world where speaking them was vital. Despite this brutality, the literacy practices to which she was exposed at school, at home and in trips with her family turned a different world into a fascinating one. Without claiming it to be traumatic, Tiago also started experiencing the wonders of English at a very young age as his parents made him take part in their love for music and cinema: My father loved to listen to music in English, like The Beatles, Bee Gees, Abba, and my parents bave always been fans of foreign movies, so the language bas always been quite familiar to my ears. Differently from Luiza and Tiago, Alexandra's learning experience of a language she at first mentioned to hate was triggered by her lack of familiarity with English. Being a fan of Harry Potter and taking part in a fanfiction group at Orkut, she had to wait five months to read the final book of the saga due to her lack of knowledge to read the English original. After an overly dramatic explanation of bow her lack of knowledge of the English language was keeping her from learning and exercising her imagination, her parents enrolled her in an English private course, a turning point in her unfinished learning trajectory. Like Alexandra's, Lucas' ongoing learning journey started with his parents enrolling him in an English course. Since he started in the first course, his interest in English as a means of access to North-American mediatic culture increased to a point that the language became an integral part of himself, his long-term life companion and the only certainty in a yet uncertain future - I may not always be a teacher, or even keep studying in this course, but I know that the language and my knowledge until now will always be by my side.

In spite of their contact with pedagogic literacy practices in language courses (Alexandra, Lucas and Tiago) or in a bilingual school (Luiza) since a relatively young age, the practices which enjoy a higher currency in their learning stories are the ones experienced in other social spheres, as the following four excerpts depict.

\section{Excerpt 1 - Alexandra}

Back then, my sister was a huge fan of Coldplay, and I started listening to it as well. A few months later, my songplayer was full of British bands, such as The Beatles, The Smiths, Stereophonics, Arctic Monkeys, Blur and my favorite, Oasis. 
Once listening to British music became a habit, translating and singing along to its lyrics became just as frequent. Consequently, I improved my pronunciation and enlarged my vocabulary without even noticing. [...]

[...] The best part about using television series as a learning device was that I would not only expand my vocabulary and learn how to pronounce certain words, but I became familiar with new accents, cultural aspects and informal expressions. For me, both television and cinematic universes were the best way to learn about a culture from a native perspective without leaving the house or having to communicate with strangers on the internet, something I was not comfortable with at the time.

\section{Excerpt 2 - Lucas}

I could say that songs and books helped me with my learning, but that would be just half true. They helped me a lot on my listening and reading skills, but, without it, I think I would be just fine. What really helped me to improve was watching TV. Yes, the great villain of parents and children's learning: Television! Watching TV shows and movies helped me to get better with my English. I have started watching subtitled movies - I will refer to everything related to Television as "Movies" - and, while doing it, I have tried to match what they said to the words on the screen, looking for the meaning of spoken expressions and even possible mistakes made in the subtitle.

But that was not enough, and I decided to challenge myself watching movies not with portuguese subtitles, but with them in english. This way, I could improve my reading, my vocabulary and the understanding of the language while seeing it being used on the screen. So, instead of looking for translations of the spoken words, I began to look for meanings. "Why did the character said this?", "Why did he point to that object when he said "chair""? Questions like those used to pop inside my head, making me relate the answers with what I already knew about the language. And, when a character from a different country spoke in the movies, for example, I could see the written word in the subtitle and then analyze the differences between the taught English in courses and the "real" english spoken through different people on the world.

\section{$[\ldots]$}

I have spent almost three years doing this job, for free, just for the sake of learning and helping people who didn't know english to watch their favorite shows. I didn't worked only in this group, and translated a lot of shows in other groups. People can see my nickname in shows like The Voice US, Weeds, Nurse Jackie, and even animations as the TV Series of The Penguins of Madagascar and Kung Fu Panda! And even in some movies, as in a new translation of the classic Lassie or in the new version of the movie Blue Lagoon. 


\section{Excerpt 3 - Tiago}

After that brief formal experience with the language, where I learned pretty much only the basic, I gained confidence to start watching series and movies and listen to music in English but in a different way, paying close attention to what they were saying and trying to grasp any words that I could or that would sound familiar to me. "Friends", "American Idol" and "Dancing With the Stars" were the first TV shows that really made me pay close attention to the language, watching it with sub titles in Portuguese and then in English like with the first two, or just with no subtitles at all, with the last one.

After getting more used to the language and gaining more vocabulary, I have decided to try and make sub titles for TV shows and here is where, I think, I gained most of what I know now. I joined the Internet teams that subtitled American Idol, Big Brother, Survivor and, later on, The Voice, I had the opportunity to get to know so many people with such great knowledge concerning the language, which really helped me grow, as an English speaker

\section{Excerpt 4 - Luiza}

I developed a passion for English literature, especially Early Modern literature, when I was around twelve and my parents took me to the Folger Shakespeare Library, in DC. The first Shakespeare play I ever watched was "Much Ado About Nothing" and it has remained my favorite play to this day. When I had to choose my High School subjects, English Literature was obviously one of my first choices.

The emotional attachment to British and/or North-American pop music, TV series, reality shows (Alexandra, Lucas and Tiago) and to classic English Literature (Luiza) reveal that the students' responsive attitudes towards what counts as legitimate literacy practices are embedded in an idealized view of native speakers and in the monolingual one nation, one language ideology. That the British and North-American varieties used by pop stars represent a high symbolic capital is revealed in Alexandra's, Luca's and Tiago's preferences concerning music and TV shows: A few months later, my songplayer was full of British bands, such as The Beatles, The Smiths, Stereophonics, Arctic Monkeys, Blur and my favorite, Oasis [Alexandra]; People can see my nickname in shows like The Voice US, Weeds, Nurse Jackie, and even animations as the TV Series of The Penguins of Madagascar and Kung Fu Panda! [Lucas]; "Friends", "American Idol" and "Dancing With the Stars" were the first TV shows that really made me pay close attention to the language [...] [Tiago]. Whereas Alexandra, Lucas and Tiago seemed to have built a linguistic repertoire of what they consider "real" English within the uses of American and British varieties in mediatic popular culture, Luiza emphasizes her love for classic English Literature, fostered by a visit to Folger Shakespeare Library in 
Washington, DC, and by the experience of watching the play Much ado about notbing with her parents. Luiza's preference for classic English Literature corroborates her evaluation that her parents were always deeply concerned with education. Given this concern, the literacy practices to which she has been exposed since her childhood are those valued by a school thought for a social elite and reinforced by parents who wish their children to succeed in such a school. Somewhere else in her autobiography, Luiza acknowledges her privileged bilingual education and that many people don't have the same luck as her and are excluded from the wonders of globalization: It is true that, in our globalized world, English is an especially important tool to add to our belt, but we shouldn't take it for granted as it is something not everyone bas the privilege of learning.

From the four excerpts above, we see that the many situations in which English is used by different linguaculture speakers are not part of the cultural commodities valued by Alexandra, Lucas, Luiza and Tiago. Therefore, rather than an orientation towards a postcolonial language ideology of World English as "a space for contestation, for claiming the periphery rights, for subversion and not submission" (RAJAGOPALAN, 2005, p. 155) ${ }^{6}$, it is the modernist ideology of language based on a native model (BAUMMAN, BRIGGS, 1990) that prevails in these student's responsive attitudes towards what count as legitimate literacy practices to learn English outside school. As Hollywoodian productions figure prominently as the best way to learn about a culture from a native perspective without leaving the bouse [Alexandra] or to have contact with real English spoken worldwide [Tiago], the many voices that use English in other meaningful practices outside the relatively developed global north seem to have no say in what count as (multi) literacies. In this sense, the otherness to which students choose to be exposed in the (inter)actions outside school they value is quite a restricted one and doesn't account for the dialectical widening (VOLOSHINOV, 1929 [1986]) of contemporary social horizons in which English represents an important semiotic resource.

Regardless of the emotional-volitional tone through which literacy practices that transcend school walls are evaluated, we notice that literacy events that characterize pedagogic literacies are brought into students' interactions with daily literacies as valid ways to foster their learning processes. These literacy events are related to the metalinguistic nature of school literacies (STREET, 1995 [2014]). They include the use of strategies such as lexical expansion: The best part about using television series as a learning device was that I would not only expand my vocabulary [...] [Alexandra], After getting more used to the language and gaining more vocabulary [...] [Tiago]; translation:

6. My translation to "[...] o World English é um espaço de contestação, de reivindicação dos direitos da periferia, de subversão e não de submissão". (RAJAGOPALAN, 2005, p. 155) 
Once listening to British music became a babit, translating and singing along to its lyrics became just as frequent. [Alexandra], After getting more used to the language and gaining more vocabulary, I have decided to try and make sub titles for TV shows [...] [Tiago]; and deducing word meanings from the context: So, instead of looking for translations of the spoken words, I began to look for meanings [...] [Lucas]. In addition to revealing these students' stances towards the relevance of these strategies, their systematic engagement with metalinguistic practices also corroborates Street's (1995 [2014]) idea concerning the imbrication between school and daily literacies as well as his position towards the ideological nature of apparently autonomous cognitive processes that characterize schooling.

When learning processes at schools, language courses or at the university become the target of students' narratives, the emotional-volitional tone is decreased to give way to more academically framed positions. As the following excerpts illustrate, Alexandra, Lucas, Luiza and Tiago then assume stances that clearly try to respond to the questions proposed by the professor (Table 2) by bringing crystallized ideologies about language and/or teaching-learning into their evaluation.

\section{Excerpt 5 - Alexandra}

Leaving my equivocated idea that I had already learned everything I could about the English language behind, I changed my course choice to English on my second semester at UFRJ. It was when I realized I still had a lot to learn. My grammar and reading classes were definitely the most demanding ones, considering it was the first time I had contact with academic papers. It took me a considerable time to get used to that type of text, but now, I feel way more familiarized with it and everything feels simpler, never less challenging.

My Oral Practice classes helped me improve my public speech posture and I taught myself how to control my anxiety in stressful moments. Since I have been struggling with this specific psychological problem for half of my life, I consider a great personal victory that I'm finally being able to fight and overcome this obstacle. The Academic Writing classes were probably the greatest responsible for me familiarizing with the academic genre. Having the opportunity to actually have a constructive feedback on your writing is definitely my favorite aspect of the class. Reading to my colleges' and teachers' peer reviews has been an enriching process and I wish I could benefit from the same technique on the next semesters.

\section{Excerpt 6 - Lucas}

Still very young, I continued my learning process in Wizard. I only spent one year there, but I can say that it was the worst year for me in terms of gathering knowledge. This course was focused on learning vocabulary and making drills for memorization. It had no communication, and the few interactions with my colleagues were limited by the book, with 
exercises that have not compelled me to go beyond what was being taught. It was a bad way of learning, because it focused too much on "perfect english", which is almost never the reality of English as a Second Language speakers. Maybe this changed along the years, but I did not stay there for too long to know.

[...]This last semester was my first as a teacher, and I have to say that this new experience was incredible. My students were there for different reasons, with different goals, and I think that I was able to share my knowledge with them. My English, Written and Oral Practice classes helped me a lot in my work, thanks to different texts and information about how to work in a classroom that I did not have before. These classes also showed me how the Communicative Approach, which I used to like since the beginning, was important for learning and using the language.

\section{Excerpt 7 - Luiza}

From reading my colleagues essays, I realize my experience with the English language has been quite different than everyone else's. Most of the stories I read involved years and years of private ESOL courses, which is something I cannot relate to and have very little experience with. What I do understand from those courses is that there is very little emphasis on "hands-on" experience, and very little effort to contextualize what one is learning.

To put it in other words, private ESOL courses tend to forget that the student will very likely use what they have learned in real-life situations, and that's something I feel very few courses_-or teachers_-prepare students for.

The way I see it, language is not something removed from context, it involves cultural background and experiences that, while common to a group, are also very personal to each speaker. The relationship I have with English is certainly different from the relationship my colleagues have. And not just because of the situation in which each of us learned this language, but also because of many other background factors just as important.

I also believe that private ESOL courses are based on a teaching model that ignores the fact that language is multicultural. We have many courses focused on one "type" of Englishusually either American or British English—when in fact there is no "American" or "British" English at all. Of course, as I mentioned, cultural issues need to be brought up in order for one to fully learn a language, but it shouldn't be limited to one culture.

\section{Excerpt 8 - Tiago}

Unfortunately, sometimes, the students have a very distorted view of what learning a new language is. It is of common sense that we have to learn and be "fluent", especially in English, because of our careers and to communicate with native speakers, but there is much more 
than that when it comes to learning a language, today most of the people who use language is not native, so why keep forcing this notion that only fluent and native speakers matter and, also when we learn a new language we don't just learn how to speak and to write, there's much more to it, that makes this process much more interesting.

Once, I read a quote from Frederico Fellini, an important Italian film director that said that "A different language is a different vision of life" and I could not agree more. When you learn a new language, you don't just learn to communicate, when you learn a new language you also learn a new country, it is not just about what the people that speak that language do it, but in which context, or why they do it that way. Learning a new language opens a spectrum of possibilities to the student of new ways to see the world and what happens in it and, for me, at the end of the day, that is the most important thing, to open minds and show a whole new world to them.

The four excerpts above indicate the students' awareness concerning how authority and authenticity are fundamental to organize power relations in academia. This consciousness is depicted by their attempt to achieve a greater level of reflexivity in their (d)evaluations about learning-teaching processes at language courses and at the university by bringing crystallized ideological systems, regarded as authoritative and authentic in the academic sphere, into the dialogue with their experiences as students and/or teachers. Addressing the professor's questions regarding the idealization of ELT in language courses and her clear expectation that they should be able to establish a critique about it (Table 2, question 2) as well as her suggestion that they look into the present to evaluate their learning processes at college (Table 2, questions 3 and 4), the four students bring a more specialized lexicon to their narratives to make their assumptions more reliable and persuasive to an academic audience (the use of terms such as academic papers, peer review, context, communicative approach, multicultural etc.). Instead of aligning to the native model and depicting English as a modern commodity to submerge into NorthAmerican or British culture (excerpts 1 to 4 ), it now becomes a semiotic resource to engage with academic literacies such as reading academic papers (Alexandra and Lucas), peer reviewing colleagues' essays (Alexandra), inter-relating theory with teaching practices (Tiago and Lucas), having access to teaching approaches that focus on communicative and situated learning (Lucas and Luiza), and to get in touch with a considerably wider otherness that include a variety of linguaculture speakers (Luiza and Tiago).

Taken into consideration that infrequent occurrences and/or silences can be more insightful to a critically intended discourse analysis (BLOMMAERT, 2005) and also to a transgressive perspective of Applied Linguistics (MOITA LOPES et al 
2006), I couldn't leave unnoticed the fact that, except for Luiza, ELT at elementary and high school is not at all mentioned in the three other autobiographies. Nevertheless, despite of the problems that Tiago, for instance, attributes to a very popular and quite huge franchise in Brazil: focus on learning vocabulary and making drills for memorization, no communication, few interactions and the focus on an illusory "perfect English", the common sense language ideology that English cannot be learned at regular schools in Brazil is pervasive in these students' life stories. This pervasiveness transcends Alexandra's, Lucas' and Tiago's narratives, as accounted by Luiza ${ }^{7}$ in the comparison she establishes between her classmates' learning stories and hers (excerpt 7, first paragraph), a comparison she uses to introduce her criticism to private ESOL courses that tend to forget that the student will very likely use what they bave learned in real-life situations. As she had the privilege of attending a bilingual school and thus never needed to go to one of these private courses, her critique of them is a projected and imaginary one. It is in this capacity of making learners' (de/re)contextualize lived or imagined experiences to perform new entextualizations about them where the potentials of learning autobiographies in future teacher's development seem to lie.

\section{FINAL REMARKS}

Aiming at concluding the ideological stances I entextualized in this paper concerning the positions that four Brazilian future English teachers construct about English, ELT and literacies in written learning autobiographies, I finish by suggesting that learning autobiographies, when approached through a dialogicideological lens, can bring meaningful contribution to pre-service teachers' development. This contribution lies mainly in the potential of autobiographies to engage future teachers in reflections about the self and the others as they perform their learning stories in (re)written narratives. Nevertheless, the expansion of a mere reflection to a (meta)reflexive awareness can be better accomplished if participants in the literacy practice of (re)narrating their learning trajectories are aware of the ideological settings through which their experiences can be (r)evaluated and (re) performed. By allowing participants to take responsive attitudes towards questions suggested by Street (2009) to orient an ideological stance towards literacies, a

7. When comparing her experiences with those of her friends', Luiza is referring to the learning stories shared by about twenty-five classmates in a forum that preceded the (re)writing of the autobiography final version. 
dialogic-ideological approach to learning stories stands as a possible path to foster further (meta)reflexivity in teacher education.

I finish with the reflective exercise of briefly addressing two among the three questions proposed by Street (2009: 337) ${ }^{8}$. "What is the power relationship between participants? Where are people going if they take on one literacy rather than another literacy?". Concerning the power relationship between participants, the analysis of Alexandra's, Lucas', Luiza's and Tiago's autobiographies showed that their awareness towards the authoritative voices which they were expected to call into the dialogue to (re)interpret their learning experiences allowed a shift from an emotional-volitional to a more academic tone. This shift not only led to a deeper (meta)reflection on their experiences, but also allowed monolingual language ideologies previously expressed in the autobiographies to be shaken. In this sense, (re)narrating their experiences in learning autobiographies created and arena where conflicting (language)ideologies compete thus allowing some disruption of the colonized views of English expressed in excerpts 1 to 4 (such as the prerogative of native speakers and the superiority of British and North American English over English as a Lingua Franca) into a more decolonized perspective which includes other cultures and speakers in the teaching-learning processes in the last set of excerpts (5 to 8 ).

Finally, the reflection about other literacies to be privileged when working with learning autobiographies in teacher education may contribute to a critical awareness towards the limitations of the literacy event focused on in this paper. Among others that may arise in future readers' responsiveness to this article, one absence that in my view stopped future teachers to ( $r$ ) evaluate their stances even further was the lack of opportunity to review their positions in other genres following the written learning autobiographies. The opportunity of (re)positioning themselves in interviews, forums, podcasts and other literacy events would certainly enhance the possibility of raising students' awareness concerning the ideologies indexed in their utterances and should be considered in further research.

\section{REFERENCES}

BAKHTIN, M.M. (1953 [1986]). Speecb genres \& other late essays. Austin: University of Texas Press.

8. The second question - What are the resources? - was explicated in the second section. 
BAKHTIN, M. M. (1920-24 [1999]). Towards a pbilosopby of the act. Austin: University of Texas Press.

BAUMAN, R.; BRIGGS, C. (1990). Poetics and performance as critical perspectives on language and social life. Annual Review of Antbropology vol. 19, pp. 59-88.

BRUNER, J. (2004). Life as narrative. Social Research vol. 3, pp.691-710.

COFFEY, S.; STREET, B. (2008). Narrative and identity in the language learning project. The Modern Language Journal vol. 92, $\mathrm{n}^{\circ}$ iii, pp. 452-464.

COFFEY, S. (2010). Stories of Frenchness: becoming a Francophile. Language and Intercultural Communication vol. 10, n², pp.119-136.

CELANI, M. A. A. (2004). Chauvinismo linguístico: uma nova melodia para um velho tema? In: Silva, F. L. S.; Rajagopalan, K. (eds.), A linguística que nos faz falbar: investigação crítica. São Paulo: Parábola Editorial, pp. 119-124.

COPE, B.; KALANTZIS, M. et al (2000). Multiliteracies literacy learning and the design of social futures. Routledge.

DEWEY, M.; LEUNG, C. (2010). English in English Language Teaching: shifting values and assumptions in changing circumstances. Working Papers in Educational Linguistics vol. 25, no 1, pp. 1-15.

GEE, J. P. (1990). Social Linguistics and Literacies: ideology in discourse. London and Philadelphia: Falmer Press.

GEORGAKOPOULOU, A. (2013). Small stories and identities analysis as a framework for the study of im/politeness in-interaction. Journal of Politeness Research vol. 9, n¹, pp. $55-74$.

HEATH, S. B. (1983). Ways with words. Cambridge: Cambridge University Press.

HOUSE, J. (2003). English as a Lingua Franca: a threat to multilingualism? Journal of Sociolinguistics vol. $7, \mathrm{n}^{\circ} 4$, pp. 556-578.

JENKINS, J. (2007). English as a Lingua Franca: attitude and identity. Oxford: Oxford University Press.

KROSKRITY, P. V. (2004). Language ideologies. In: Duranti, A. (ed.), A Companion to Linguistic Antbropology. Blackwell Publishing, pp. 496-517. 
LEFFA, V. J. (2002). Teaching English as a multinational language. The Linguistic Association of Korea Journal vol. 10, n 1, pp. 29-53.

LEUNG, C.; STREET, B. (2012a). Introduction: English in the curriculum - norms and practices. In: Leung, C.; Street, B (eds.), English a changing medium for education. Multilingual Matters, Kindle Edition.

LEUNG, C.; STREET, B. (2012b). Linking EIL and literacy: theory and practice. In: Alsagoff, L. et al (eds.), Principles and practices for teaching English as an International Language. London and New York: Routledge, Kindle Edition: chapter 6.

MOITA LOPES, L. P. et al (2006). Por uma Linguística aplicada indisciplinar. São Paulo: Parábola.

MOITA LOPES, L. P. (2008). Inglês e globalização em uma epistemologia de fronteira: ideologia linguística para tempos híbridos. D.E.L.T.A. vol. 24, n² 2, pp. 309-340.

MOITA LOPES, L. P. et al. (2013). O português no século XXI: cenário geopolítico e sociolinguístico. São Paulo: Parábola Editorial.

OLIVEIRA, M. B. F.; SZUNDY, P. T. C. (2014). Práticas de multiletramentos na escola: por uma educação responsiva à contemporaneidade. Revista Bakbtiniana vol. 9, n 2, pp.184-205.

PAVLENKO, A. (2001a). Language learning memoirs as a gendered genre. Applied Linguistics vol. $22, n^{\circ} 2$, pp. 213-240.

PAVLENKO, A. (2001b). In the world of tradition I was unimagined: negotiation of identities in cross-cultural autobiographies. The International Journal of Bilingualism vol. $5, \mathrm{n}^{\circ} 3$, pp. 317-344.

PAVLENKO, A. (2007). Autobiographies narratives as data in Applied Linguistics. Applied Linguistics vol. $28, \mathrm{n}^{\circ} 2$, pp. 163-188.

RAJAGOPALAN, K. (2004). The concept of 'World English' and its implications for ELT. ELT Journal vol. 58, n 2, pp. 111-117.

ROMERO, T. R. S. et al. (2010). Autobiografias na (re) construção de identidades de professores de linguas: o olhar crítico-reflexivo. Campinas, SP: Pontes.

SANDHU, P. (2014). The interactional and narrative construction of normative and resistant discourses about Hindi and English. Applied Linguistics vol. 35, n 1, pp. 29-47. 
SEIDLHOFER, B. (2011). Understanding English as a Lingua Franca. Oxford: Oxford University Press.

SILVERSTEIN, M.; URBAN, G. (1996). The natural history of discourse. In: Silverstein, M.; Urban, G. (eds.), Natural bistories of discourse. Chicago and London: The University of Chicago Press, pp. 1-44.

SILVERSTEIN, M. (1998). The uses and utility of ideology: a commentary. In: Schieffelin, B. B.; Woolard, K. A.; Kroskrity, P. V (eds.), Language ideologies practice and theory. Oxford: Oxford University Press, pp.123-145.

STREET, B. (1984). Literacy in theory and practice. Cambridge: Cambridge University Press.

STREET, B. (1995). Social literacies: critical approaches to literacy in development, ethnography and education. Longman Group Limited.

STREET, B. (1995 [2014]). Letramentos sociais: abordagens críticas do letramento no desenvolvimento, na etnografia e na educação. Trad. Marcos Bagno. São Paulo: Parábola Editorial.

STREET, B. (2000). Literacy events and literacy practices. In: Martin-Jones, M.; Jones, K. E. (eds.), Multilingual literacies: comparative perspectives on research and practice. Amsterdam: John Benjamin’s, p.17-29.

STREET, B. (2009). Ethnography of writing and reading. In: Olson, D. N.; Torrance, N. (eds.), The Cambridge handbook of literacy. Cambridge University Press: 2009, pp. 329-345.

SZUNDY, P. T. C. (2013). Formação inicial e continuada de professores como ato responsável: (trans)formações de uma pesquisadora-multiplicadora'. In: XXXXX, P. T. C.; Barbara, L. (eds.), Maria Antonieta Alba Celani e a Linguística Aplicada: pesquisadoresmultiplicadores em (inter) ações. Campinas: Mercado de Letras, pp. 57-82.

SZUNDY, P. T. C. (2014). Educação como ato responsável: a formação de professores de linguagens a luz da filosofia da linguagem do Círculo de Bakhtin. Trabalhos em Linguística Aplicada vol. 53, n 1, pp.13-32.

SZUNDY, P. T. C. (2017). Language ideologies on English as a Lingua Franca in Brazil: conflicting positions expressed by undergraduate students. The Journal of English as a Lingua Franca vol. 6, n 1, pp. 167-192.

SZUNDY, P. T. C.; FABRÍCIO, B. F. (2019). Linguística Aplicada e indisciplinaridade no Brasil: promovendo diálogos, dissipando brumas e projetando desafios. In: 
SZUNDY, P. T. C.; Tílio, R.; Melo, G. C. V. (orgs.), Inovações e desafios epistemológicos em Linguística Aplicada: perspectivas sul-americanas. Campinas, SP: Pontes Editores, pp. 63-89.

VITANOVA, G. (2004). Gender enactments in immigrants' discursive practices: bringing Bakhtin to the dialogue'. Journal of language, identity and education vol. 3, n 4, pp. 261-277.

VOLOSHINOV, V. N. (1929 [1986]). Marxism and the philosopby of language. Harvard University Press.

WOOLARD, K. A. (1998). Introduction. In: Schieffelin, B. B.; Woolard, K. A.; Kroskrity, P. V. (eds.), Language ideologies practice and theory. Oxford: Oxford University Press, pp. $3-47$.

WORTHAM, S. (2001). Narratives in action: a strategy for research and analysis. New York: Teachers College Press.

Recebido: 26/09/2019

Aceito: 15/12/2019

Publicado: 28/02/2020 